UDK: 321.728(439)"20"

DOI: https://doi.org/10.18485/25bghun.2021.ch23

\title{
KRASZTEV PÉTER
}

Budapesti Gazdasági Egyetem

\section{Az illiberális áfium: ellen-valóság. Magyarország és Európa kétpólusú társadalmai}

\begin{abstract}
Összefoglaló
A tanulmány a Magyarországon 2010-ben létrejött és 2014-ben bejelentett „illiberális” rendszer különböző magyarázatait és értelmezéseit veszi számba, majd megpróbálja a problémát egy egyszerre történelmi-kultúrtörténeti és kognitív pszichológiai értelmezési keretben elhelyezni. Az írás abból az antropológiai indíttatásból indul ki, hogy nem maga az illiberális rendszer az érdekes, hanem egyfelöl a motiváció, mely ezt létrehozta, másfelől pedig a tömeges igény a szimulált valóságra, illetve az emóciókra építő irracionalitásra. A hasonló tipológiai jegyeket mutató, azaz „hasadt” társadalmakkal való összevetés után az a következtetés vonható le, hogy az ilyen módon történelmileg sérült közösségek sokkal védtelenebbek a felvilágosodás normáiból táplálkozó racionális társadalmi normákat tagadó, valóságformáló narratívákkal szemben, mint a kevésbé rögös modernizációs utat bejárt társadalmak, ezért jobban ki vannak téve az autoriter hajlandóságú politikai erők hatásának.
\end{abstract}

Kulcsszavak: illiberalizmus, hasadt-kettészakadt társadalmak, politikai racionalitásirracionalitás, új autoritarizmus, hibrid rendszerek, Közép- és Kelet-Európa.

A tanácsadó azt mondta, hogy a magamfajta fickók ,abban léteznek, amit valóságalapú közösségnek nevezünk", ami - az ő meghatározása szerint - olyan embereket jelent, akik „abban hisznek, hogy a megoldások a megtapasztalható valóság mélyreható tanulmányázásából születhetnek”. Bólintottam és dünnyögtem valamit a felvilágosodás eszméiről és az empirikus megismerésről. 
A szavamba vágott: „A világ már nem így müködik. - És folytatta. Ez itt most egy birodalom, és amikor cselekszünk, azzal egy új valóságot teremtünk. És amikor te azt a valóságot vizsgálod mélyrehatóan, mint rendesen - mi újfent cselekszünk, újabb valóságokat teremtünk, melyeket szintén lehet vizsgálni, és ez így megy majd tovább. Mi történelmi szereplők vagyunk... te pedig, és ti mindannyian, arra lesztek kárhoztatva, hogy azt tanulmányozzátok, amit mi teszünk."

Ron Suskind felidézi a beszélgetését G. W. Bush egyik tanácsadójával (2004) ${ }^{1}$

A távoli 1973-as esztendőben a szovjet hatóságok egy hipertitkos akciót hajtottak végre: Novoszibirszk közelében üzembe helyeztek egy akkumulált bioenergiával müködő Radioszon (rádióálom) elnevezésü berendezést, mellyel egy szempillantás alatt sikerült álomba szenderíteni egy ötvenöt kilométerre fekvő, száz négyzetkilométer területü város teljes lakosságát. Az eljárást csehszlovák parapszichológiai laboratóriumokban fejlesztették ki, és a Szovjetunóban alkalmazták először sikerrel.

A fenti történet, minden bizonnyal, szovjet apokrif legenda, mely évtizedek óta visszatérő motívum a KGB-ről szóló bulvártörénelmi kiadványokban, kvázivisszaemlékezésekben és áldokumentumokban. ${ }^{2}$ Szép is lett volna, ha ennyire egyszerủen megbabonázhattak volna egy városnyi populációt. Annyi viszont tény, hogy a magát a „történelmi materializmus” alapjaira helyező, a látszat szintjén maximálisan racionalista szovjet (és minden más szovjet típusú) diktatúra suttyomban folyamatosan kacérkodott a parapszichológiával és bioenergetikával,

\footnotetext{
${ }^{1}$ https://www.nytimes.com/2004/10/17/magazine/faith-certainty-and-the-presidency-of-george-wbush.html legutóbbi megtekintés 2020. április 29. Itt és a továbbiakban - ahol külön nem jelezem az idegen nyelvü szövegeket saját fordításban közlöm.

${ }^{2}$ A Radioszon-történetet egy meglehetősen kétséges módszerrel dolgozó szerző, Olga Grejg írja le a könyvében, de hivatkozásokat nem találni benne (Grejg 2014: 267). Kernbach orosz nyelvü könyvében épp erre hivatkozik a Radioszon-ügyben (2015: 117), vagyis ennek a hitelessége is erősen kétséges. Sajátos módon a legsemlegesebb és -informatívabb forrás egy rövid időrendi leírás, mely megtalálható például itt: http://ezolife.info/?p=6559 legutóbbi megtekintés 2020. április 29.
} 
parafenoménekkel és természetgyógyászokkal, telepátiával és pszi-hadviseléssel, hol közvetlenül támogatva ezek kutatását, hol alkalmazva ezek „eredményeit” az autokrácia hétköznapi gyakorlatában³ ${ }^{3}$. A Radioszon-történet inkább egy ábrándot fogalmaz meg: egy autoriter rezsim ábrándját, miszerint nemcsak erőszakkal és elnyomással tudja irányítani az alattvalók magatartását, hanem rálelhet egy ennél kifinomultabb és észrevétlenebb „áfiumra”, mellyel a lakosság akaratát manipulálni tudja.

A némileg formabontó kezdés után az itt következőkben az elképzelhető legkonvencionálisabb eljárást fogom követni: először röviden összefoglalom, milyen fogalmakat vagy metaforákat vetett be néhány avatott szerző a racionálisan amúgy nehezen értelmezhető magyarországi helyzet értelmezésére, majd javasolok egy saját koncepciót, mely nem annyira magát a helyzetet akarja körül- vagy leírni, hanem az irracionalitás könnyü térhódításának az okát keresi a hazaihoz hasonló - talán történelmileg, talán kulturálisan - kettészakadt társadalmak kontextusában. A fenti, némileg excentrikus példával csak érzékeltetni szerettem volna, hogy még a magát a legracionálisabbnak, leginkább cél- és észvezéreltnek beállító világátalakító rendszer is hajlandó volt átlépni a saját ideológiai elkötelezettségén, ha ettől a valóság gyors és költséghatékony megváltoztatását remélte. Vagyis az irracionalitás mindig is kurrens eszköz volt az önkényuralom kezében, esetleg annyi különbséggel, hogy két és fél évtizeddel később az ezotéria már teljesen kikopott a hatalom valóságteremtő eszköztárából (véletlen, mégis szimbolikus egybeesés: Moszkvában épp abban az évben eresztették szélnek a Kreml kórházának fóállású parafenoménjait, amikor a mottóban olvasható párbeszéd lezajlott az USÁ-ban ; v.ö. Kuzina: 2005), az empirikus és megtapasztalhatón túli „hipervalóság” közötti határvonal mára mégis elmosódott.

3 Például: General KGB o pszi-oruzsii. (A KGB tisztje a pszi fegyverről) https://cont.ws/@romster/126500 és a cáfolat: https://sputnikipogrom.com/russia/47872/kgblunatics/. legutóbbi megtekintés 2020. április 29. 
Ebben az írásban azt állítom, hogy az illiberális demokrácia kikiáltása nem egy új államideológia látomása, hanem egy közbülső eszköz, rituális kellék, varázsige (esetleg maga az ,áfium”), mely rendeltetése szerint ,átsegíti” a közösséget az empirikus valóságból a politikai szándék által teremtett „új transzcendenciába”. Sok szempontból az történik, ami az államszocialista rendszerben: a cél mindenképpen a kontrolláltalan hatalom folyamatos kiterjesztése és fenntartása, amihez elengedhetetlen az állampolgárok cselekvésének befolyásolása; a nem elhanyagolható különbség pedig az, hogy az új körülmények között fel kell hagyni a fegyelmező erőszak alkalmazásával (illetve a kuriózumszámba menő ezoterikus erőlködéssel), és fenn kell tartani a szabad választás látszatát, amiben az azóta kifejlesztett kommunikációs technikák kreatív alkalmazása komoly támaszt jelent. Kérdés persze, hogy egyes társadalmakban miért nagyobb a fogadókészség erre az irracionalitásra, amit szintén igyekszem érzékeltetni néhány történeti és kognitív pszichológiai megfigyeléssel.

\section{Értelmezések illiberalizmusra}

Az ,illiberális demokrácia” bejelentése 2014 júniusában történt meg Orbán Viktor miniszterelnök szokásos tusnádfürdői beszédében, ahol rendszerint a politikai direktívákat szokta megadni hívei számára ${ }^{4}$. Az időpontnak nincs sordöntő jelentősége, hiszen a liberális, liberalizmus a közbeszédben már előtte is szitokszókét forogott közszájon Magyarországon, a nemzetvesztő, hitetlen, idegenszívü, (nemzeti) radikális kontextusban szimplán a zsidó szinonimájaként használták ${ }^{5}$. Társadalomtudósok és véleményformáló értelmiségiek körében közhelynek számított, hogy a 2010-es választási győzelem után a Fidesz illiberális politikát folytat/nézeteket vall/ideológiát hirdet/magatartást tanúsít/stb. A politikai filozófusok, politológusok és egyéb elméleti hajlandóságú elemzők

\footnotetext{
${ }^{4}$ https://www.youtube.com/watch?v=LiTMBxKJhx 8

5 Nem igazán igényes, de szimptomatikus megnyilatkozása ennek egy 2007-es keltezésủ blogbejegyzés https://molnargoreny.blog.hu/2007/06/06/liberalisok_toleranciaja (legutóbbi megtekintés 2020. április 29.) Ennél jóval szofisztikáltabban 1. Lányi, 2015, a „rejtjelezett” liberáliszsidózásra Bogár László nagyívü mủve szolgál jó példával (2006).
} 
határon innen és túl már a 2010-es fordulat óta szériában gyártják a fogalmakat, értelmezési kereteket, kategóriákat és metaforákat, melyekkel az új helyzetet értelmezni tudják. Eddig száznál is több tanulmány, kötet és elemző esszé jelent meg a témában, az interjúkat és cikkeket nem is számoltam.

A legfrissebbek közül az egyik legfajsúlyosabbnak számító megszólalóval, Francis Fukuyamával kezdeném, akinek a sokat idézett és vitatott müve, a Történelem vége és az utolsó ember 1992-ben a racionalitás diadalát ünnepelte. Ebben azt a tézist vetette fel, hogy a kétpólusú világrend felbomlásával az emberiség elérte az ideológiai fejlődés csúcspontját, hiszen a nyugati típusú liberális demokráciák a létező legfejlettebb államrendet testesítik meg, onnan már nem vezet tovább az út. Különös, hogy a már akkor is sokszorosan meghaladott evolucionizmusnak (és neoevolucionizmusnak) ez a sajátos szellemi hajtása hogyan válthatott ki ekkora hatást a müvelt világban - akkoriban feltehetően mindenki ebben akart hinni. Azután jöttek a jugoszláviai háborúk, a nyomukban létrejött nacionalista rezsimek, Szlovákiában a mečiari illiberális próbálkozás, majd a közel-keleti háborúk, a terrortámadások, az arab tavasz és az európai „tarka forradalmak”, a putyini „eurázsiánizmus” jegyében elkövetett agressziók, s mindez a legkevésbé sem a történelem végnapjait sejttette. Jó negyedszázaddal később, visszatekintve az akkori téziseire, Fukuyama némileg értetlenül konstatálta, hogy a világ egy jó része épp az ellenkező irányba indult el, Magyarország pedig, a demokratikus átalakulás egykori mintaállama ennek a folyamatnak is az élmezőnyében halad: „Úgy érzem, az egyik nyomasztó gondolat, mely néha eszembe jut az - nyilatkozza egy némileg konfúzus gondolatmentet lezárva Fukuyama -, hogy a történelem vége nem egy olyan ország, mint Dánia, vagy Németország. Olyan, mint Magyarország: ez egy illiberális demokrácia, mely rendelkezik egy bizonyos fokú demokratikus legitimitással, mutatkozik bizonyos szándék, hogy demokratikus kormányzást valósítson meg, ugyanakkor rendkívül korrupt” (MacDowall 2019). A nagyhatású politikai gondolkodó mintha ezúttal sem ásna túl mélyre, és utólag sem vesz tudomást arról, hogy az illiberalizmus épp az általa megálmodott liberális 
racionalitást ütötte ki a képzeletbeli ideológiai nyeregből, hanem a tüneteket mutatja be a baj okozójaként.

Talán a legnépszerübb, és külföldön is legjobban piacosítható tézis a már említett „rabul ejtett állam” gondolatkörét viszi tovább. Magyar Bálint volt liberális miniszter családi üzletként írja le az államot az autoriter fordulat után, amelyben senki más előtt nem nyílnak gazdasági lehetőségek, aki nem a patriarchális családfő környezetéhez tartozik (Magyar 2013: 1015). És ez nyilván igaz is, csak mivel a gazdaság még mindig tartja magát, ez azt jelentené, hogy a rokonság és az oligarchai kör mégsem annyira tehetségtelen, hogy bedöntse a rendszert. Vagy esetleg mások is beléphetnek a körbe, és akkor a tétel máris veszít az erejéből.

Mások az „elitek árulásához” kötik a demokrácia romlását. Jaque Rupnik és a hozzá hasonlóan érvelők a ,polarizációs tézissel” - végsőkig leegyszerüsítve - azt állítják, hogy a rossz, normaszegő politikusok felrúgták az 1989 óta gyakorlatilag kétpólusú politikai térben addig meglévő „liberális minimum” konszenzusát, és jobboldali egyeduralmat építettek ki. Hatalmuk megtartása érdekében feladták a retorikában addig irányadó ,politikai korrektséget” (ami helyi szinten amúgy sem volt túl igényes), és kisajátították, államfüggővé tették a gazdasági eliteket, megfosztva ezzel az ellenfeleket a külső támogatástól. Ez a populizmus térnyerésével és a politikai ellenfél megsemmisítésével jár, s ez ráadásul költséges játék, amihez csak korrupciós hálózatokon keresztül lehet megszerezni a pénzt (Rupnik 2012). És ebben is bizonyára van igazságuk, de milyen politikus az, aki húsz éven keresztuil nem vette észre, hogy nem Norvégiában vagy Angliában él, ahol a gentlemen's agreement még a politikusok között is értelmezhető fogalom. Jelentősen árnyalja a képet a szerzőnek egy Jan Zielonkával közösen jegyzett cikke, mely nem a liberális doktrína gyakorlati talajvesztését panaszolja, hanem a nyugati demokratikus minták átvételének kudarcát konstatálja Közép- és KeletEurópában, és ennek okát az informális, és ebből következően áttekinthetetlen (gazdasági, hatalmi, politikai) hálózatok térnyerésében látja (Rupnik-Zielonka 2013). Ez a megközelítés már sokkal érzékenyebben utal a megváltozott 
kontextusra, ahol a láthatatlan, informális struktúrák alakítják a valóságot (nem véletlenül jutnak a szerzők arra a helytálló következtetésre, hogy egy ponton túl ennek felderítését inkább az antropológia, nem pedig a politikatudomány illetékességébe kellene utalni), de arról a szerepről, amit az illiberális fordulat ebben játszik, nem fordítanak külön figyelmet. A kvázi-valóság körülírásához talán Ágh Attila jut a legközelebb, aki részben épp a Rupnik-Zielonkatanulmányra támaszkodva „Patyomkin-demokráciának” nevezi a Magyarországon létrejött politikai rendszert (Ágh 2015), de mintha ő sem látná, hogy a politikai Patyomkin-homlokzatot kétmilliónál is több szavazó őszinte hite tartja egyenesben - egy hit, amelyet, per def., a racionális argumentáció és a tények érintetlenül hagynak.

Valamennyire köthető az előbbi tézishez az „alulteljesítő liberalizmus” koncepció, melyet például Ivan Krastev képvisel, mely föként annak tulajdonítja az auteriter fordulatot, hogy a liberalizmus rosszul teljesített Magyarországon, nem váltotta be a hozzá füzött gazdasági reményeket, ráadásul még nagyobb szegénységet és vagyoni különbségeket eredményezett (Krastev 2016). Hasonlóan érvelnek azok, akik a liberalizmus általános válságával kapcsolják össze a demokrácia magyarországi hanyatlását, talán annyi finomítással, hogy ők az újonnan létrehozott intézmények merevségében, személytelenségében is olyan tényezőt látnak, mely elriasztotta az embereket a demokrácia alapértékeitől. A Steven Holmesszal közösen írt politikatörténeti bestsellerben, az Elhalványult fény. Leszámolásban Krastev már sokkal árnyaltabb álláspontot képvisel. A szerzők, ha közvetve is, de félreérthetetlenül a közép- és kelet-európai emberek vágyaira és elvesztett illúzióira, vagyis az illiberális fordulat mögötti emocionális tartalomra hivatkoznak. abban a korban, amikor Fukuyama „történelem vége” metaforája berobbant a köztudatba, a közvélemény a „normalitásra”, nyugalomra vágyott, ennek lett a hívószava a liberális demokrácia, követendő mintája pedig a nyugati társadalmi berendezkedés. Az 2000-es évek végére ez a lendület alábbhagyott, a nyugati minta elveszítette a varázsát, a liberalizmus minden idegennek a szinonimájává lett, s felértékelődött a saját út vágyálma - ennek a 
hívószava lett a diadalmas „illiberalizmus” (Holmes-Krastev 2019). Ha ezt a nagyívü magyarázatot egybefüzzük Rupnik és Zielonka konklúziójával, akár teljes képet is kaphatnánk a végbement fordulat okairól, de a kivételekre, mint Szlovákia és Csehország, vagy akár a korrupciós hálózatokban ugyan szintén jeleskedő, de a liberális alapelveket a retorika szintjén elfogadó és az EU-s kötődést soha meg nem kérdőjelező Romániára és Bulgáriára ez a magyarázat nem igazán alkalmazható. Ráadásul a - Holmes-Krasztev értelmében vett nyugati mintáktól elforduló magyarországi szavazók kezdetben a radikális jobboldalon gyülekeztek (v.ö. Tóth-Grajczjár 2015: 133-166), tehát a választók rögtön az elitváltást követően talán nem lettek volna annyira fogékonyak az antiliberalizmusra vagy illiberalizmusra, ha a magukat liberálisnak aposztrofáló politikusok megtanultak volna érthető nyelven kommunikálni a tömegekkel.

Az egyik legnépszerübb értelmezési keret a kulturális hagyományokra vezeti vissza a demokratikus értékek hirtelen érvényvesztését. A magyar liberális filozófusok, mint Heller Ágnes (2018), Vajda Mihály (2018), Bretter Zoltán (2014), Kis János (2013), de még az író Spiró György (2017) is ilyen-olyan módon a demokratikus hagyományok történelmi hiányára, a választható történelmi minták szükösségére hivatkoznak, vagyis körülbelül azt állítják, hogy a nyugati mintákra kiépült liberális intézmények tartalom nélkül maradnak, hiszen sem a „gulyáskommunizmus”, sem a horthysta autokrácia nem adhatott kellő demokratikus muníciót ezek feltöltésére. Sajátos, hogy az imént felsoroltak logikáját követő külföldi szerzők is leggyakrabban a nacionalista-antiszemita múltra hivatkoznak, ennek visszatérését látják az illiberális populizmus népszerüségében. A kulturális érvelés rendszerint azért ingoványos, mert egy európai viszonylatban átlagos történelemmel (pl. nem a 20. században keletkezett államalakulat) rendelkező ország esetében a múlt rendszerint kínál olyan mozzanatot, tényt vagy helyzetet, mely egy adott tézist alátámaszt vagy cáfol; ezekkel a kérdés sokkal inkább az, mennyire hozott létre a felidézett tény olyan mintázatot, mely örökségként adódik tovább a nemzedékek között. És ha már hagyományról és örökségről esik szó: a legkülönösebb az, hogy szinte egyetlen 
elemző sem reflektál érdemben arra, hogy Magyarországon található Európa három legdrasztikusabban kettéosztott társadalmának egyike. Mára sokan elfelejtették, de a korai, még radikálisan demokrata Fidesz egyik fö küldetésének tekintette ennek a kettéosztottságnak a felszámolását: azért hívták magukat „elvált szülők gyermekének”, mert elutasították a népies-urbánus, keleti-nyugati orientáció (de még a politikai jobb és bal) közötti választást. Pedig az illiberális fordulat első mozdulata akkor történt meg, amikor feladták ezt az elhatározást ${ }^{6}$.

És ezzel az interpretációk sora még messze nem ért véget. A rendszerkritikusok, élükön Peter Wilkinnel, váltig állítják, hogy a magyar illiberalizmus a globális kapitalizmus válságának és tarthatatlanságának eredménye, a Fidesz rezsimje pedig egy „autoriter neoliberalizmus”, mely a nacionalista retorikát a nemzeti burzsoázia megerősítésére használja (Wilkin 2016). Mások, mint például a kiváló elemző, Pogátsa Zoltán (2016) és a volt pénzügyminiszter, Bod Péter Ákos (2018) a „fejlesztő állam” távol-keleti koncepcióját látják megvalósulni az etatista, protekcionista és a gazdaságot erősen centralizáló törekvésekben, melyek valójában a nemzetközi versenyképesség növelését célozzák. Lássuk be, ez azért meglehetősen jószándékú értelmezése annak, amit a magyar köznyelv egyszerủen kleptokráciának nevez, pedig a tanulmányokból kiderül, hogy a szerzők nem pártolják a 2010 utáni rendszert. Igaz, az az előttit sem.

Mindent összevetve azonban a legnagyobb karriert a politológusok körében a Way és Levitski amerikai elemzők által bevezetett „hibrid rezsim” fogalom futotta be (2010). Bozóki András és számos kollégája úgy látja, hogy a hatalom megtartotta ugyan a demokrácia külsődleges attribútumait, az intézmények látszólag funkcionálnak, csakhogy épp úgy és épp annyira alakították át ezeket, hogy minden mozzanatukkal az aktuális hatalom érdekeit szolgálják (Bozóki és

\footnotetext{
${ }^{6}$ Orbán Viktor lényeges, liberalizmusra és ideológiára vonatkozó idézetei időrendi sorrendben itt olvashatók: https://hirklikk.hu/kozelet/orban-a-maga-asta-godorbl-akarkimaszni/353751?fb_comment_id=2902172279854315_2902285286509681 legutóbbi megtekintés 2020. április 29. Az ideológiaváltás kontextusát forrásértékủ interjúkban Petőcz György dolgozta fel (2001).
} 
Hegedüs 2018). Ilyen ,patyomkinfalu” a választás, mely formálisan szabad ugyan, de egy új választási törvénnyel manipuláltak, az alkotmánybíróság, mely hozhat ugyan ítéletet, de a tagjait a párt választja ki, független föügyész, aki konkrétan párttag, bíróságok, melyek döntéseit egy föléjük helyezett szervezet felügyeli, és a sor szinte a végtelenségig folytatható (Bozóki 2015; Krasztev 2014).

\section{Hibridizálódás és megkettőződés}

Érdemes egy pillanatra megállni a „hibrid” kifejezésnél, mely más kontextusban ugyan, de a posztmodern elméleteknek is kedvelt metaforája volt és a fent idézett szerzők szellemében 1979-ben bukkan elő először Alekszandar Ahiezer orosz társadalomtörténésznél. A mára gyakorlatilag elfelejtett liberális gondolkodó ezzel a meghatározással illette a majdani posztkommunista attitüdöt, melyről szó szerint úgy gondolja, ,a liberalizmuson kívül a haszonelvűség lesz még jelen benne, ennek különböző változatai, és ennek elemei fognak egybefonódni a tradicionalizmussal" (Ahiezer 1991: 301). Monumentális, több mint ezer oldalas művének a kulcsszava a „hasadás”, ami minden jelentős történelmi eseménynél megosztja az orosz társadalmat - a kereszténység felvételétől a „zavaros időkön” és a Nagy Péter-i reformokon, valamint a 19. századi falu-város-szakadáson, valamint a nyugatos (zapadnyik) - népies (pocsvenyik) konfrontáción át a „nagy októberi tragédiáig” - és más társadalmakkal ellentétben semmiféle integratív mechanizmus nem alakult ki arra, hogy ezek a törésvonalak elsimuljanak. A történelemben ciklikusan visszatérő jelenségeket mutat ki: az egész konstrukciót körülbelül úgy lehet elképzelni, mint egy Mengyelejev-táblázatot, ahol a jövőnek szánt cellák még üresek ugyan, de főbb sajátságaik leírhatók, s utólag - mint a mellékelt idézet is mutatja - a feltételezések beigazolódnak. A, nyilván, név nélkül előre jelzett (putyini) autoriter, ha úgy tetszik ,hibrid” rendszernek ez a logika még egy-két évet szán. A kéziratot a KGB 1982-ben elkobozta, de Ahiezer nyolc évi munkával 
rekonstruálta, és 1991-ben jelent meg barátai anyagi támogatásával. Magányban és szegénységben halt meg Moszkvában, ahol az egész életét leélte.

Majtényi György bon mot-ja szerint a magyar történész egyik ismérve, hogy „kizárólag történészeket olvas (poéták helyett is)” (Majtényi 2014). Bármilyen örömteli is látni, milyen kreatív energiákat szabadít fel a politológusokból ez a jelenlegi rezsim, bármilyen derekasan is vitatkozgatnak egymással, mégis kísért a gondolat, hogy a fenti mondás közülük sokakra is érvényes. Mert olvashatnának például történészeket. Mondjuk, épp Ahiezert, a mindhalálig elkötelezett, liberális tudóst, akinek a szellemét azért idéztem itt meg, mert ő pontosan érzékelte a különbséget hagyomány és örökség között, pedig se mintázatokról, se mémekről nem beszélt még akkor senki ${ }^{7}$. És ez azért ad egy másik dimenziót annak a kérdésnek, hogy vajon miért épp abban a három európai országban honosodott meg a legmakacsabbul az illiberalizmus, ahol a leginkább kettéhasadt a társadalom: Magyarországon, Törökországban és Oroszországban. (Izrael és Lengyelország specifikus eset, egy kis messianizmusért ők sem mennek a szomszédba, de ott még sérülékeny az autoriter illiberalizmus.) Ezek azok a diktatúrából kilábalt országok, ahol a birodalmi tudat (a Nagy-Magyarországtudatot lehet ennek leképződésének tekinteni Magyarország esetében) átöröklődő kulturális mintázatokat hoz létre, melyek nem képesek alkalmazkodni az időközben átalakuló történelmi valósághoz, s ez olyan mértékben torzítja az önképet, gátolja a szembesülést a saját múlttal, hogy a többség egy jól irányzott „emlékezetpolitikai mutatvánnyal” emocionálisan manipulálható. Agárdi Péter, ha nem is túl élesen, de legalább a tudati tényezőkre összpontosítva ezt így fogalmazza meg:

A magyar kultúra szerkezetének, modelljeinek, értékkészletének és infrastruktúrájának század eleji radikális átalakulása objektív természetű, társadalmi gyökerü, „materiális” folyamat. Az erre

\footnotetext{
7 A hagyomány és örökség (,tradition” vs. „legitimacy”) tárgykörben mélyreható elemzést olvashatunk Maria Todorova megkerülhetetlen múvének 7. fejezetében (The Balkans: RealiaQu'est-ce qu'il y a de hors-texte?) (2009: 161-183).
} 
reflektáló, de egyúttal azt ösztönző-gerjesztő kánonváltás, illetve a konzervatív és új az értéknormák ütközése, a modern nemzeti liberális és demokratikus kultúrafelfogás kihordása viszont inkább tudati, ideológiai, „szellemi” jelenség. Együttesüket s föleg eredményeiket mai távlatból joggal minősíthetjük kultúraváltásnak a magyar müvelödés történetében, amelyet 100 év múlva, a 2000 körüli ezred-, illetve századfordulón egy újabb követ, illetve ír fölül. (2012)

És még ha a politológusoknak kétségtelenül igazuk is van abban, hogy az illiberális fordulathoz kellenek rossz politikusok, kell egy gyengén kommunikáló, magát liberálisnak mondó elit, kell a társadalmi egyenlőtlenség növekedése, a kapitalizmus általános válsága és a nyugati mintájú modernizációs stratégiák kifulladása, a vágyakhoz, ábrándokhoz és félelmekhez ezeknek alig van köze. Márpedig a 2010 utáni politikai elit - a leghathatósabb kommunikációs stratégiák bevetésével ${ }^{8}$ - épp ezekhez férkőzött hozzá, és a háttérmunkát a több ezres apparátust mozgató mega-think-tankre, a Századvég Intézetre bízza - nyilván azoknak a pénzéből, akiket aztán „visszamanipulálnak” a saját vágyaikkal és szorongásaikkal. Nagyon sommásan összegezve: egy tudatilag-kulturálisan kettészakad társadalomnak valamelyik része mindig vágyik az ábrándjai beteljesülésére, és mindig az nyer, aki képes megteremteni a nagyobbik hányad vágyképeinek megfelelő virtuális valóságot.

Egy kulturálisan hasadt országban mindenből kettő van: két művészeti akadémia, két írószervezet, két jazz- és két színházi szövetség, két civil társadalom - a miénk és az övék. Magyarországra legalább annyira érvényes az, amit George Lakoff kognitív pszichológus és nyelvész Amerikáról mond: „A kettéválasztottság az agyunkban fészkel - abban, ahogy az amerikaiak értelmezik a világot. Ott találjuk a két egymással versenyző gondolkodási modellt, mely az

\footnotetext{
${ }^{8}$ Ennek a mechanizmusairól itt olvashatunk: https://24.hu/belfold/2019/01/14/soros-gyorgy-fideszkampany-arthur-finkelstein-george-birnbaum/(Legutóbbi megtekintés 2020. május 1.)
} 
országunk kormányzásának két ellentétes módjához vezet: az egyik az alapvetően demokratikus, a másik pedig az alapvetően antidemokratikus" (2009: 5). Ijesztően esszencialistának és deterministának hangzik a megállapítás, mégis kísértetiesen összecseng korunk talán leghatásosabban szintetizáló elméjének, Yuval Hararinak a liberalizmus elméleti felülvizsgálatára buzdító nézeteivel. Az izraeli történész ugyanis pontosan rámutat arra, mitől vesztette el vonzerejét és hatékonyságát ez az ideológia a hétköznapi politizálásban: a liberalizmus a racionalitás mítoszában érvényesül, az ember márpedig fiziológiailag, a neuronok szintjén nem racionális lény. „A népszavazások és választások nem a racionalitásról szólnak, hanem az érzelmekröl” - szögezi le (2018: 51), vagyis aki a hatalmat akarja, annak elég egy koherens történetet adnia a saját, Lakoff-fal együtt nevezzük ,antidemokratikus” oldalnak, és mindegy, igaz, vagy hazug: az embereknek vissza kell fecskendezni az agyukba a saját, új formába öntött tündérmeséjüket. Mondjuk, KertMagyarországot, Kompországot, Híd-Magyarországot - van elég történelem és szerző, akinek a metaforáiból lehet válogatni, a post-truth korában minden igaz lehet, vagyis igazzá tehető. Persze, mire föl kárhoztatjuk ,mitomániájukért” a közép-ázsiai etnikai rokonokkal turult pörkölő, vagy rovásírásos táblákat kihelyező, nemzeti egységről fantáziáló honfitársainkat, amikor mi is csak hívők vagyunk, felvilágosodás-determinált racionalisták, akiknek téves elképzelései vannak a racionalitásról. Mert, mint Lakoff megállapítja:

A progresszívek az értelemnek egy régi, még a felvilágosodásból eredő felfogásából indulnak ki, nevezetesen abból, hogy az értelem tudatos, szó szerint értelmezendő, logikus, egyetemes, indulatmentes, önmagában való és egyéni érdekeket szolgál. A kognitív tudományok és az agykutatás ezzel szemben azt igazolják, hogy ez hamis elképzelés az értelemröl. Bármily furcsa is, ennek van jelentősége. Tudományos kérdésnek tünik, de az értelem természetéről vallott nézetek a demokrácia hatékony védelmének és fejlesztésének az útjában állnak. (2008: 2) 
Márpedig a felvilágosodás racionalitásán iskolázott liberális elme ezzel máig semmit sem tud kezdeni. Pedig Ahiezer már 1979-ben óva intett: „Nem szabad elfelednünk, hogy az összemberi történelem szempontjából a liberális értékek csak vékony jégkéreg a tradicionalizmus vastag rétegein" (1998: 785). Figyelemre méltó intuíciói: ez a jég be is szakadt alattunk, és az ideológusok az alatta lévő a rétegekben kotorásznak új mesék után, vagy ahogy Harari mondja: ,a liberalizmus összeomlása után maradt ürt lassanként kezdik betölteni a nemzeti aranykorról szóló nosztalgikus ábrándok” (2018: 23). Az illiberalizmus volt az a belépőkód, melynek hatására végleg kitárult a kiüresedett térbe, a teremtett valóságba vezető kapu, melyen már senkinek sem kellett átcipelnie a felvilágosodás racionalizmusának terheit.

Mióta a politikai küzdelem nem programok és látomások között zajlik, hanem arról szól, ki teremt vonzóbb valóságot, a demokratikus oldal szénája rosszul áll.

A progresszívok, kitudja, miért, hatalmas elönyt adtak a konzervatívoknak a kultúrharcban. A radikális konzervatívok máris megkeresték és elkezdték bevezetni azt az autoriter hierarchiát, mely a vagyon felhalmozásán és a javak ellenőrzésén alapul; egy olyan rendszert, ami a félelmen, megfélemlítésen és engedelmességen alapul; korlátozott hatáskörü kormányon; a hatalmi ágak egyensúlyának hiányán; olyan rendszeren, mely nem a közszférát részesíti előnyben, hanem az üzleti és a katonai érdekeltségeket; mely a társadalmi felelősséget az egyénre hárítja; mely ellenőrzése alá vonja a választásokat azáltal, hogy ellenőrzi a szavazatokat és ezek összeszámlálásának a módját; mely ellenörzése alatt tartja az eszméket a média felügyelete által; mely a patriarchális viszonyokat teszi meg példaképnek. (Lakoff 2009: 1)

Ezt a némileg hosszúra hagyott idézet akár a 2010 utáni hazai viszonyok forgatókönyve is lehetett volna. Nehéz megítélni, mennyire követ bizonyos törvényszerüségeket minden autoriter hatalom, és mennyire követi a szomszédok 
gyakorlatát, vagy reagál a gyakorlatban az ellenfelek elméleti felvetéseire. Egyes sajtóértesülések szerint, Harari Orbán egyik kedvenc szerzője, még személyes konzultációra is meghívta ${ }^{9}$. Érdekes eljátszani a gondolattal, hogyan reagálna a politikus a történésznek arra a felvetésére, hogy a technológiai forradalmak lehagyják a politikai haladást, és ezzel talán a politikusok által bevezetett mesterséges valóság is szertefoszlik. Persze, már az is előrelépésnek számítana, ha az írásom második részében idézett szerzők csak egy pillanatra kilépnének a saját, racionálisnak gondolt valóságukból, és az ellenfél teremtett valóságára reflektálnának egy másik, még vonzóbb valósággal, mint javasolja ezt Lakoff egy korábbi (2004), szintén alapmünek számító Ne gondolj az elefántra címü könyvében (ebben az általa kidolgozott és azóta a kommunikációs szakemberek suta kezei között gyakran a paródia szintjére profanizált framing-elmélet gyakorlati használhatóságát mutatja be). Igen, felelhetnék erre, de a „mi oldalunk” termeli a nemzetközileg piacosítható akadémiai tudást. Lehet, de az „övék” kitermeli belőle a hasznot.

\section{Keleti kitekintés - az orosz példa}

Mint említettem, nehéz utánajárni annak, mennyi az átvétel, és mennyi a pusztán tipológiai hasonlóság a hasonló logika szerint müködő autoriter rezsimek ideológiája között. Vlagyiszlav Szurkov, akit „Putyin Raszputyinjaként” szoktak emlegetni, és a posztmodern vagy inkább post-truth politikai porhintés meglehetősen ügyes machinátora, tavaly februárban jelentette meg manifesztumát Putyin hosszú országlása címen (Szurkov 2019). A számos szövegszerü áthallás Orbán ünnepi beszédeivel (pl. lerázzuk magunkról a Nyugat nyomasztó terhét, a jelenlegi kormányzati formában találta meg a nemzet önmagát, mi vagyunk a nemzeti egység záloga, most teljesítjük be a történelmi küldetésünket, felébresztjük Európát stb.) sokkal kevésbé meglepö, mint az, hogy mintha már a

\footnotetext{
${ }^{9}$ Erről részletesen itt lehet olvasni: https://index.hu/belfold/2017/12/04/yuval_noah_harari_homo_deus_sapiens_konyv_orban_viktor _kedvenc_konyve/ (Legutóbbi megtekintés 2020. április 29.)
} 
címmel a tíz éve megboldogult, saját hazájában alig ismert Ahiezernek akarna üzenni. A kiáltványban azután többször is szóba kerül az orosz történelem, nyilván sajátos interpretációban, de az ahiezeri ciklusok szerinti bontásban. Nyilván nem is említi a nevét, de Hararira és Lakoffra sem hivatkozik, holott az ő érveikkel intézi el a Nyugatot jelképező liberalizmust. Külön kitér arra, hogy a nyugati elemzők őrjöngenek, mert nem értik az orosz választók paranormális viselkedését, a populizmusnak tudják be, mert nincs rá más szavuk, pedig bele kell törődniük, hogy idővel egyre több országban ez lesz a mértékadó választói magatartás. A szóválasztás itt nem véletlen, nem is teszi a szót idézőjelbe: a paranormális túlmutat az irracionális választói magatartáson, átvezet az okkultba, a misztikus szellemi közösségbe (oroszul: szobornoszty), mely évszázadok óta az orosz eszme egyik központi ideológiai pillére. Talán úgy képzeli, hogy ez az egyedülálló spiritualitás úgy áramlik majd szét Oroszországból, mint annak idején a proletár világforradalom eszméje és gyakorlata.

Szurkov azonban nem megszállott, csak jól aknázza ki a racionális tudománynak az emberi irracionalizmusról szerzett tudását, azaz kitermeli belőle a hasznot: arra támaszkodik, amit Lakoff mond az értelemröl, mely természetéből adódóan nem racionális. És ennek a felismerésnek a következményei valóban túlnőnek az akadémiai viták keretein: Alekszandr Dugin „eurázsiai” elmélete, mely a 90-es évek vége óta lassan belenőtt a putyini illiberális állam ideológiájába, rendkívül eklektikus, de alkotórészeinek egyetlen közös eleme az emberek érzelemeire ható irracionalitás, amibe a fundamentalista ortodox hittől az okkultizmuson át az olasz típusú fasizmusig minden belefér (a több tucatnyiból csak egy jellegzetes, sok nyelven megjelent könyve: Dugin 2000). Eszméi nyomokban felfedezhetők a bolgár Ataka, a görög Sziriza és a Jobbik ideológiájában, de a magyar illiberalizmus prófétájának, az első Orbán-kormány vezető ideológusának, Bogár Lászlónak a fő művében felismerhetők a Dugin-féle „posztmodern spiritualizmus” főbb tézisei (Bogár 2006).

Mindezzel nem azt szerettem volna sugallani, hogy a spirituális közösségtudat, az irracionális eszmekörök - a mitikus nemzeteszmétől a globális összeesküvés- 
elméletekig - az antidemokratikus és illiberális politikai rendszerek melegágya, esetleg eredője lenne. Épp ellenkezőleg: a liberalizmus elutasítása nyitja meg ezek felé az utat, az illiberalizmus ott visszhangzik a politikai vezetők aktuális retorikájában, az irracionális félelemre építő kampányokban, a propagandisztikus emlékezetpolitikában. Korunk autoriter rezsimjei felismerték ennek a (Durkheim klasszikus fogalmával élve) „varázsnak” a lélektani erejét, a mindennapi kommunikációjuk részévé tették, és ezzel átrendezték a társadalmon belüli értékhatárokat, átértelmezték a forradalom szabadság-egyenlőség-testvériség értékrendjét, és úgy irányítják híveik „paranormális” viselkedését, ahogy a kezdetben említett novoszibirszki Radioszon projekt megálmodói el sem tudták volna képzelni.

\section{Konklúzió folyamatban}

Minden társadalomtudomány legsérülékenyebb pontja az írás jelen idejéhez való viszonya. Mind ennek az írásnak a szerzője, mind pedig olvasója egy olyan 2010 óta tartó folyamatnak a részese, résztvevője, részben alakítója (stb.), mely az írás megszületése és elolvasása után is folytatódni fog. Ráadásul a társadalomtudósnak nem dolga a jövendölés, Ahiezerből egy volt, ő már megadta a maga prognózisát, más társadalomtudósnak ez nem állna jól. Valójában az elmúlt két és fél ciklus alatt Magyarországon a - Lakoff fogalmai szerint progresszív, demokratikus indíttatású, vagyis a felvilágosodás racionális normáihoz igazodó emberek megpróbáltak mindent (és annak az ellenkezőjét is), gyakorlatilag kimerítette az ellenállási formák minden lehetőségét - a pártoktól a bázisközösségekig, környezetvédőktől a fegyveres testületekig, a diákoktól a pedagógusokig, az egészségügyi dolgozóktól a mezei internetfelhasználókig (végül még a szakszervezetek is) mind ellőtték a puskaporukat, ellepték az utcákat, kikötözték magukat, botrányt csináltak a parlamentben és a köztévében, elfoglaltak közterületeket, költöttek saját dalokat, szerveztek flash-mobokat, gyüjtöttek aláírást - minden úgy ment, mint máshol, csak épp az átütő hatás maradt el. Már szinte csak a történelmi egyházak nem mozgósítottak a hatalom 
ellen, de az ő forradalmi hajlandóságukra nem mernék fogadni a jelen helyzetben. Soha nem egyesült egy közös akaratba a rengeteg különálló próbálkozás, egészen a 2019 őszi önkormányzati választásokig. Ezt hívja a hatalom „központi erőtérnek": együtt kell tartani a saját hívők táborát, a kommunikációnak folyamatosan termelnie kell a látszatvalóságot, táplálnia kell az ábrándokat (amilyen - többek között - B. Anderson [1991] és S. Sand [2017] értelmezésben a nemzet) és félelmeiket (migránsok, Soros), a többieket viszont egyenlő távolságra kell tartania önmagától és - föként - egymástól, hogy soha ne tudjanak egymással szövetkezni, legalább annyira ódzkodjanak egymástól, mint amennyire meg akarják dönteni a regnáló hatalmat. Ez rengeteg pénzt és energiát felemészt, de egyelöre ezen múlt a fennmaradásuk: a több tucatnyi különbözö, egyenként érvényes racionalitást, érvet, aspektust nem egyesíti egy közös vágykép, miközben az emóciókra építő irracionális valóságból csak egy van.

A diadalmas racionalitás, a dübörgő modernitás daliás korában, konkrétan 1858-ban Abraham Lincoln még bátran kijelenthette: „bolondíthatod az embereket egy ideig, bolondíthatsz néhány embert mindig, de nem bolondíthatsz mindig mindenkit" ${ }^{\prime 10}$. Csakhogy a post-truth korában ez legfeljebb szép, de nem vigasztaló: a „matrixnak” egyre erősebb a szívóhatása, beszivárgott az intézményekbe, a gazdaságba, a közbeszédbe, a párhuzamos valóság, amelyet Suskind még félénken emleget 2004-ben megteremtette az alternatív történelmét, hiedelmeit, rítusait, és egyre kevesebben biztosak abban, hol végződik a simulacrum, és mi van rajta túl. A sérült, kettéhasított társadalmakban csak akkor alakulhat ki a napjainkban annyit emlegetett nyájimmunitás az irracionalizmussal szemben, ha erre közös akarat mutatkozik (erre szokták a háború utáni Németországot felhozni példának). De lehet, hogy ebben is Hararinak lesz igaza: a nagyon sok hatalom vakká teszi a birtokosait arra a valóságra is, melyet ők maguk kreáltak, és akkor összeomolhat az egész építményük (2018: 205-206). És ezzel azért felcsillantja a remény szikráját.

\footnotetext{
${ }^{10}$ Egy relatíve hiteles forrás szerint ez az eredeti mondás a köztudatban lévővel ellentétben http://abrahamlincolnassociation.org/you-can-fool-all-of-the-people-lincoln-never-said-that/
} 


\section{Bibliográfia}

Agárdi Péter 2012. Kultúravesztés vagy kultúraváltás?

https://digitalia.lib.pte.hu/www/free/agardi-peter-kulturavesztes-vagy-

kulturavaltas-pte-feek-pecs-2012/htm/index.html (legutóbbi megtekintés 2020. 04. 29.)

Ágh Attila 2015. De-Europeization and De-Democratisation Trends in ECE: from the Potemkin Democracy to the Elected Autocracy in Hungary. Journal of Comparative Politics. 8 (2). 4-26.

Ahiezer, Alekszandr 1998. Rosszija: krityika isztoricseszkogo opita. (Szociokulturnaja gyinamika Rosszii). (Oroszország: a történelmi tapasztalat kritikája. (Oroszország társadalmi-kulturális dinamikája). Novoszibirszk, Novoszibirszkij kronograf. Első kiadás: 1991, Moszkva: Filoszofszoje obscsesztvo SZSZSZR.)

Anderson, Benedict 1983. Imagined Communities. London: Verso.

Bod Péter Ákos 2018. Bérek, profitok és járadékok harca - magyar szemmel. Századvég (2) $51-76$.

Bogár László 2006. Magyarország és a globalizáció. Budapest: Osiris.

Bozóki András és Hegedűs Dániel 2018. An externally constrained hybrid regime: Hungary in the European Union. Democratization. 25 (7) https://www.tandfonline.com/doi/full/10.1080/13510347.2018.1455664 (legutóbbi megtekintés 2020. 04. 29.)

Bozóki András 2015. Broken Democracy, Predatory State, and Nationalist Populism In: The Hungarian Patient: Social Opposition to an Illiberal Democracy, Szerk. Krasztev Péter és Van Til, Jon. Budapest: CEU Press. 3-36.

Bretter Zoltán 2014. Halfway or no way? Politeja 2(28). 5-30.

Dugin, Alekszandr 2000. Osznovi geopolitiki. Moszkva: Artktogea.

Fukuyama, Francis 1992. The end of History and the Last Man. NY: The Free Press. Magyarul: 1994. A történelem vége és az utolsó ember. ford. Somogyi Pál László, jegyz. ford. M. Nagy Miklós, Budapest: Európa.

Grejg, Olga 2016. Eksztraszenszi i magi v szpecszluzsbah mira (Parafenomének és mágusok a világ titkosszolgálatainak szolgálatában), Moszkva: Algoritm.

Harari, Yuval Noah 2018. 21 lecke a 21. századról. Budapest: Animus.

Heller Ágnes 2018. What Happened to Hungary? New York Times, Szeptember 16. https://www.nytimes.com/2018/09/16/opinion/politics/what-happened-tohungary.html (legutóbbi megtekintés 2020. 04. 29.)

Holmes, Steven és Krastev, Ivan 2019. The Light that Failed: A Reckoning. NY: Pegasus Books.

Kernbach, Szergej 2015. Szverhesztyesztvennoe. Naucsno dokazannie fakti (A természetfeletti. Tudományosan igazolt tények), Moszkva: Algoritm. 
Kis, János 2013. Az összetorlódott idő. Beszélő Online.

http://beszelo.c3.hu/onlinecikk/az-osszetorlodott-ido-\%E2\%80\%93-masodiknekirugaszkodas (legutóbbi megtekintés 2020. 04. 29.)

Krastev, Ivan 2016. Liberalism's Failure to Deliver. Journal of Democracy 27(1):35-38.

Krasztev Péter 2014. Social Responses to the "Hybridisation" of the Political System The Case of Hungary. Alkalmazott tudományok első fóruma. Konferenciakötet. Szerk. Solt Katalin. Budapest: A Budapesti Gazdasági Egyetem Kiadványa. 492502.

Kuzina, Szvetlana 2005. Kremljovszkih eksztraszenszov otpravili v otsztavku. (Kirúgták a Kreml parafenoménjait) Komszomolszkaja pravda. Jan 5.

Lakoff, George 2004. Don't Think of an Elephant! Chelsea, Vermont; Chelsea Green Publishing. Magyarul: 2006, Ne gondolj az elefántra. A progresszív gondolkodás nélkülözhetetlen zsebkönyve. Budapest: Napvilág Kiadó.

Lakoff, George 2009. The Political Mind. A Cognitive Scientist's Guide to Your Brain and Its Politics. London: Penguin Books.

Lányi András 2015. Eltorzult liberális alkat, zsákutcás rendszerváltozás.

https://mandiner.hu/cikk/20150617_lanyi_andras_eltorzult_liberalis_alkat (legutóbbi megtekintés 2020. 04. 29.)

Levitsky, Steven és Way Lucan 2010. Competitive authoritarianism: Hybrid regimes after the Cold War. New York, NY: Cambridge University Press.

MacDowall, Andrew 2019. Fukuyama -- the end of history could look like Hungary. https://www.intellinews.com/vox-fukuyama-the-end-of-history-could-look-likehungary-157727/ (legutóbbi megtekintés 2020. 04. 29.)

Magyar Bálint (Szerk.) 2013. Magyar Polip: A posztkommunista maffiaállam. Budapest: Noran Libro.

Magyar Bálint (Szerk.) 2015. A magyar maffiaállam anatómiája. Budapest: Kossuth Kiadó.

Majtényi György 2014. A történelem fegyver. Beszélő online. http://beszelo.c3.hu/onlinecikk/a-tortenelem-fegyver (legutóbbi megtekintés 2020. 04. 29.)

Petőcz György 2001. Csak a narancs volt. Budapest: Irodalom KFT kiadása.

Pogátsa Zoltán 2016. Magyarország politikai gazdaságtana - Az északi modell esélyei. Budapest: Osiris Kiadó.

Rupnik, Jacques 2012. Hungary's Illiberal Turn: How Things Went Wrong. Journal of Democracy 23 (3):132-37.

Rupnik, Jacques és Zielonka, Jan 2013. The State of Democracy 20 Years on: Domestic and External Factors. East European Politics and Societies. 27 (3): 1-25.

Sand, Shlomo 2017. Twilight of History. London, New York: Verso. 
Spiró György 2017. Demokráciának nálunk a diktatúrák közti átmenetet nevezik. HVG online

https://hvg.hu/itthon/20171206_Spiro_Demokracianak_nalunk_a_diktaturak_kozt i_atmenetet_nevezik (legutóbbi megtekintés 2020. 04. 29.) továbbá:

https://mta.hu/data/dokumentumok/szima/szekfoglalok/Spir_Gy_rgy_sz_kfoglal _.pdf (legutóbbi megtekintés 2020. 04. 29.)

Suskind, Ron 2004. Faith, Certainty and the Presidency of George W. Bush. New York Times. https://www.nytimes.com/2004/10/17/magazine/faith-certainty-and-thepresidency-of-george-w-bush.html (legutóbbi megtekintés 2020. 04. 29.)

Szurkov, Vlagyiszlav 2019 Dolgoe goszudarsztvo Putina (Putyin hosszú országlása) http://www.ng.ru/ideas/2019-02-11/5_7503_surkov.html (legutóbbi megtekintés 2020. 04. 29.)

Todorova, Maria 2009. Imagining the Balkans. NY: Oxford University Press.

Tóth, András és Grajczjár, István. 2015. The Rise of Radical Right in Hungary. In Krasztev, P. és Van Til, J. (szerk.) The Hungarian Patient: Social Opposition to an Illiberal Democracy. Budapest: CEU Press. 133-66.

Vajda Mihály 2018. Ránk sem jellemző, hogy meg akarnánk érteni a másik oldalt. Vajda Mihály. Interjú. http://www.marosvasarhelyiradio.ro/musorok/rank-semjellemzo-hogy-megakarnank-erteni-a-masik-oldalt-vajda-mihalyinterju/?utm_source=mandiner\&utm_medium=link\&utm_campaign=mandiner_2 02005 (legutóbbi megtekintés 2020. 04. 29.)

Wilkin, Peter 2016. Hungary and the Road to Serfdom. Lanham, Maryland: Lexington Books. 


\title{
The Illiberal Opium: Counter-Reality. Bipolar societies of Hungary and Europe
}

Péter Krasztev, Budapest Business School

\begin{abstract}
The paper provides a brief overview of the interpretations of the so-called illiberal political system in Hungary which was introduced after the 2010 parliamentary elections and was officially announced by the prime minister in 2014. The author argues that the object of the analysis should not be the illiberal system itself but rather the motivation behind its implementation as well as the massive need of the majority of the population to adopt a simulated reality based on irrational exploitation of human emotions. After using a comparative approach, mostly inspired by social, historical and cognitive-psychological argumentation, the study makes an attempt to interpret some divided societies which show similar typological features. The conclusion drawn is that the historically damaged societies have developed less efficient mechanisms for defence from those political narratives which deny the rational norms originating from the spirit of Enlightenment and are more likely to except the fake reality offered by the non-democratic political forces, therefore, they are more exposed to the danger of the newly emerging authoritarian regimes.
\end{abstract}

Keywords: Central and Eastern Europe, illiberalism, divided-split societies, hybrid regimes, political rationality-irrationality, new authoritarianism.

\section{Iliberalni opijum: kontra-stvarnost. Bipolarna društva Mađarske i Evrope \\ Peter Krastev, Univerzitet ekonomskih nauka u Budimpešti}

\section{Sažetak}

Ovaj rad predstavlja kratak pregled interpretacija tzv. ,iliberalnog” političkog sistema u Mađarskoj, koji je usledio posle parlamentarnih izbora 2010, a zvanično je proglašen od strane premijera 2014. godine. Autor zagovara to da predmet analize ne treba da bude iliberalni sistem sam po sebi, već motiv iza njegove implementacije, kao i ogromna potreba da većina populacije usvoji simuliranu stvarnost utemeljenu na iracionalnoj eksploataciji ljudskih emocija. Služeći se komparativnim pristupom, najviše inspirisanim društveno-istorijskom i kognitivno-psihološkom argumentacijom, ova studija će pokušati da interpretira neka podeljena društva koja pokazuju slične tipološke osobine. Zaključak je da su istorijski oštećena društva razvila manje efikasne mehanizme odbrane od političkih narativa koji poriču racionalne norme proizašle iz duha prosvetiteljstva, a sklonija su prihvatanju lažne stvarnosti koju nude nedemokratske političke snage, pa su time i izloženija opasnostima od novonastajućih autoritarnih režima.

Ključne reči: Centralna i Istočna Evropa, iliberalizam, podeljena društva, hibridni režimi, politička racionalnost, novi autoritarizam. 